\title{
The structure of the plankton community of the Öregrundsgrepen (southwest Bothnian Sea)
}

\author{
S. ERIKSSON, C. Sellei \& K. Wallström \\ Institute of Zoology, Uppsala University; Uppsala, Sweden
}

\begin{abstract}
Taxonomic composition and variations in density and biomass of the plankton community in the Oregrundsgrepen, a shallow coastal area, were investigated from June 1972 to November 1973. The phytoplankton biomass was large in spring but small during the rest of the year. The spring bloom was dominated by diatoms and dinoflagellates, especially by Thalassiosira spp. which were also important during other seasons. Small forms, such as Cryptomonas spp., Rbodomonas spp. and monads, dominated during summer. Blue-green algae were never of any major importance. During the summer, the trophogenic layer exceeded $10 \mathrm{~m}$ in thickness. The metazoan fauna was of lower diversity than the plankton flora. The dominating species, the copepods Acartia bifilosa and Eurytemora affinis, constituted on the average $83 \%$ of the standing crop. The low salinities, $5-6 \% \mathrm{~S}$, were regarded as the principal pertinent limiting factor. The metazoan fauna reached large biomass values from July to October. The protozoan fauna (in the case of ciliates), obtained biomass maxima during the spring bloom. It is suggested that the Oregrundsgrepen represents an area of elevated productivity within a region of low overall production, presumably due to local upwelling. From June 1972 to May 1973, the average biomasses were: phytoplankton $0.464 \mathrm{~g} \mathrm{C} \mathrm{m}^{-2}$, ciliates $0.040 \mathrm{~g} \mathrm{C} \mathrm{m}^{-2}$, copepod nauplii $0.010 \mathrm{~g} \mathrm{C} \mathrm{m}^{-2}$, micro-rotifers $0.004 \mathrm{~g} \mathrm{C} \mathrm{m}^{-2}$, and mesozooplankton (larger than $0.2 \mathrm{~mm}) 0.312 \mathrm{~g} \mathrm{C} \mathrm{m}^{-2}$. It is estimated that about than $60 \%$ of the phytoplankton production is consumed by the microzooplankton $(<0.2 \mathrm{~mm})$.
\end{abstract}

\section{INTRODUCTION}

Much interest is being placed on studies of the energy flow through different parts of the marine ecosystem. Of great significance are the dynamics of the earlier steps in the food chains, i.e. within the phyto- and zooplankton. This paper deals with the structure of the plankton community from June 1972 to November 1973 in a shallow coastal area in the southwest Bothnian. Sea, the Oregrundsgrepen (Fig. 1). Special emphasis has been placed on long series of intensive sampling at one easily accessible station, several samples on every sampling occasion, and a thorough taxonomical analysis of the biocoenosis. The relative importance of micro- and mesozooplankton was regarded of particular interest. It is hoped that this study will provide useful information for future modelling work on the Baltic ecosystem.

Not much is known about the phyto- and zooplankton of the Bothnian Sea. However, valuable surveys have been made by Anonymous (1912), Hessle \& Val- 


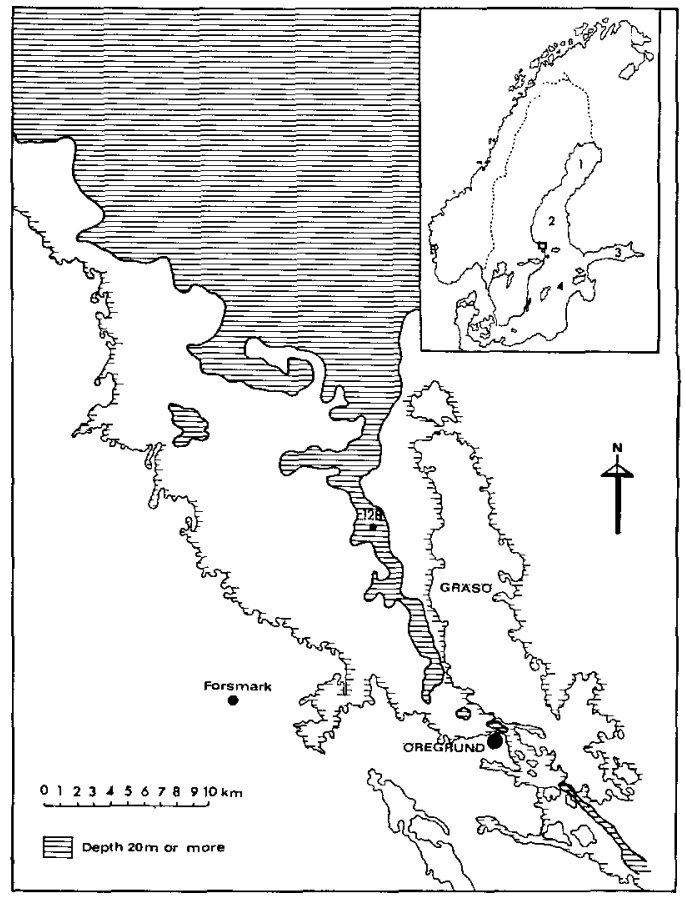

Fig. 1: The Oregrundsgrepen. Sampling Station 128 is located in the channel coming from the Bothnian Sea over a depth of $45 \mathrm{~m}$. Inset: Subvivisions of the Baltic, (1) Bothnian Bay, (2) Bothnian Sea, (3) Gulf of Finland, (4) Baltic proper. The rectangle denotes the investigation area

lin (1934), and Lindquist (1959). Data on primary production and/or phytoplankton biomass may also be obtained from Schnese (1969), Bagge \& Lehmusluoto (1971), Fonselius (1972), and Ackefors \& Lindahl (1975a, 1975b). Separate zooplankton taxa have been dealt with by some authors; Limnocalanus grimaldi De Guerne $(=L$. macrurus) has been investigated by Lindquist (1961) and Eurytemora sp. (=E. affinis) by Hernroth. Pejler (1972) reported on the rotifer fauna of sheltered bays.

\section{STUDY AREA}

The Oregrundsgrepen is subjected to intensive investigations on general marine ecology, fisheries biology, and hydrology by the Swedish Natural Environment Protection Board, the Institute of Zoology at Uppsala University, and the Swedish Meteorological and Hydrological Institute. The area will soon be the recipient for cooling water from the nuclear power plant at Forsmark (Fig. 1). The plankton fauna was preliminarily surveyed during the summer 1970 by Eriksson (1973b). A paper on the ecology of Eurytemora affinis and Acartia bifilosa will be published elsewhere (Eriksson, in press). 
The Oregrundsgrepen is influenced by a main system of currents of brackish water giving a stable salinity of 5 to $6 \% 0 \mathrm{~S}$. However, winds may modify the situation. The predominant winds are SE and NW. The former wind direction causes lower temperature and the latter higher temperature and somewhat less saline water. Winds from the SW give rise to upwellings along the mainland. During the summer, rapid temperature change indicates mobility of the water mass. During the investigation period there was a temperature stratification at Station 128 from May to September (Fig. 2). The surface temperature may exceed $18^{\circ} \mathrm{C}$ in July and August. The coldest month was March with $1^{\circ} \mathrm{C}$ in the whole water column. As a result of the mild winter 1972-1973, the area was only occasionally covered by thin ice from December to March.

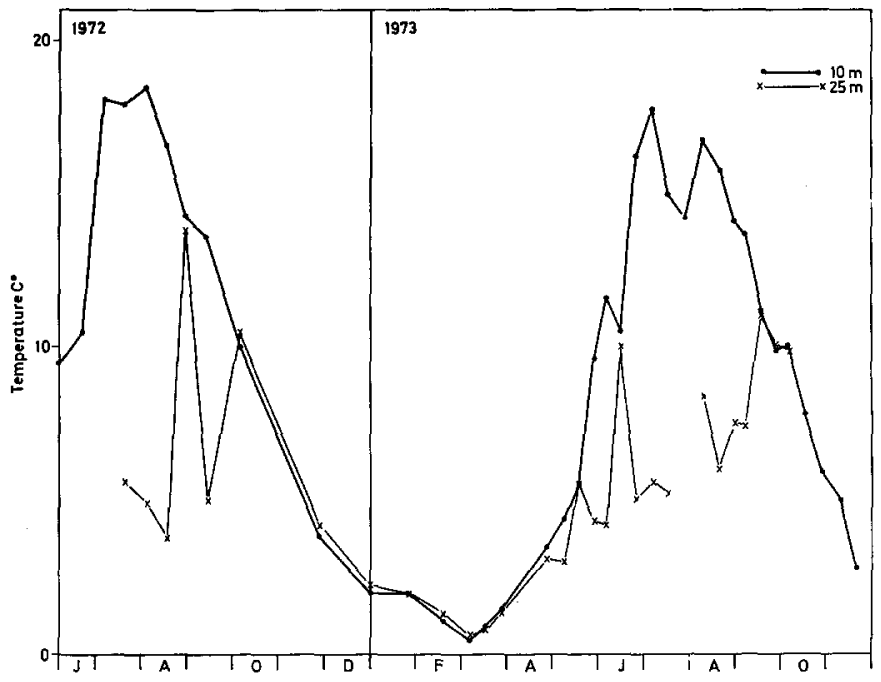

Fig. 2: Temperature curves for Station 128, June 1972-November 1973

The bottom topography of the investigation area is rather complicated with a depth less than $10 \mathrm{~m}$ (Fig. 1). A deeper channel stretches in along Gräsö Island from the Bothnian Sea which is here about $50 \mathrm{~m}$ deep. The channel becomes increasingly shallow and is only $20 \mathrm{~m}$ deep off the town of Oregrund. The sampling station (Station 128) is located in this channel over a depth of $45 \mathrm{~m}$.

The field samplings were usually made twice a month during 1972 and three times a month during 1973. All samples were collected at full daylight.

Phytoplankton and protozoan plankton were sampled with a 2.81 Ruttner sampler at .5, 1, 3, 5, 10, 15 and $25 \mathrm{~m}$. From each depth $200 \mathrm{ml}$ water was preserved with Lugol's solution and a few drops of $40 \%$ foraldehyde solution. The temperature was read from a mercury thermometer mounted in the sampler. In the laboratory, subsamples of 50 or $100 \mathrm{ml}$ were poured into sedimentary tubes. After $48 \mathrm{~h}$ the different taxa were enumerated by using an inverted microscope technique based on Utermöhl (1958). The magnifications were $\times 100$ and $\times 400$. 
Metazoan plankton was sampled with a Nansen net with a mouth diameter of $50 \mathrm{~cm}$, mesh size $.09 \mathrm{~mm}$, and a Tsurumi flow meter mounted at the centre of the mouth. The filtering efficiency of the net was $40 \pm 9 \%(x \pm s)$. On each sampling occasion 4 vertical hauls were made from a depth of $40 \mathrm{~m}$ to the surface. In the laboratory, they were diluted to $1500 \mathrm{ml}$ and 5 subsamples of $15 \mathrm{ml}$ were examined. For samples with small numbers of metazoan plankton the dilution was only 250 to $500 \mathrm{ml}$.

Biovolumes were calculated by multiplying the numerical density of each taxon by standard figures on volume of the whole organism. No corrections were made for vacuoles, empty volumes in thecae etc. Phytoplankton values were obtained from Melvasalo (unpublished) and Hobro (unpublished) and metazoan plankton from the Water Conservation Laboratory, Helsinki, Finland (unpublished). Supplementary measurements were made on some phytoplankton taxa and all protozoan plankton taxa.

\section{RESULTS}

\section{Composition of the plankton community}

The separate taxa into which the biocoenosis have been divided are listed in Table 1. Small flagellated algae which were impossible to diagnose in preserved condition have been collected under the heading "monads". For taxonomical remarks on the plankton fauna reference should be made to Eriksson (1973b). Two subspecies of Keratella quadrata have been recorded, viz. K. quadrata quadrata in cold water from January to May and $K$. quadrata platei in warmer water during the rest of the year. Since many authors regard as significant the occurrence of these two subspecies, a special study is needed to find out whether they are true subspecies or only an example of cyclomorphosis.

Tables 1 and 2 illustrate that the diversity of the plankton flora is considerably larger than that of the plankton fauna.

\section{Seasonaldistributions}

The density is given as the number of cells $\mathrm{m}^{-3}$ for all phytoplankton and protozoan plankton taxa except for the filamentous species Aphanizomenon flosaquae. The metazoan plankton taxa are presented as the number of specimens $\mathrm{m}^{-3}$.

Aphanizomenon flos-aquae reached its highest density during September-October in 1972 (Fig. 3). During 1973 the species appeared earlier and reached its peak densities somewhat earlier. The figures were considerably higher in 1973.

Pyrmaimonas sp. is a numerous species. It showed similar seasonal distributions during 1972 and 1973 although the figures were higher in 1973. Peak densities were reached during July-September. Oocystis spp. occurred during the whole investigation period but in relatively low density. The taxon mainly appeared during the summer and autumn with the highest peaks in 1972. 
Table 1

Composition of the plankton community

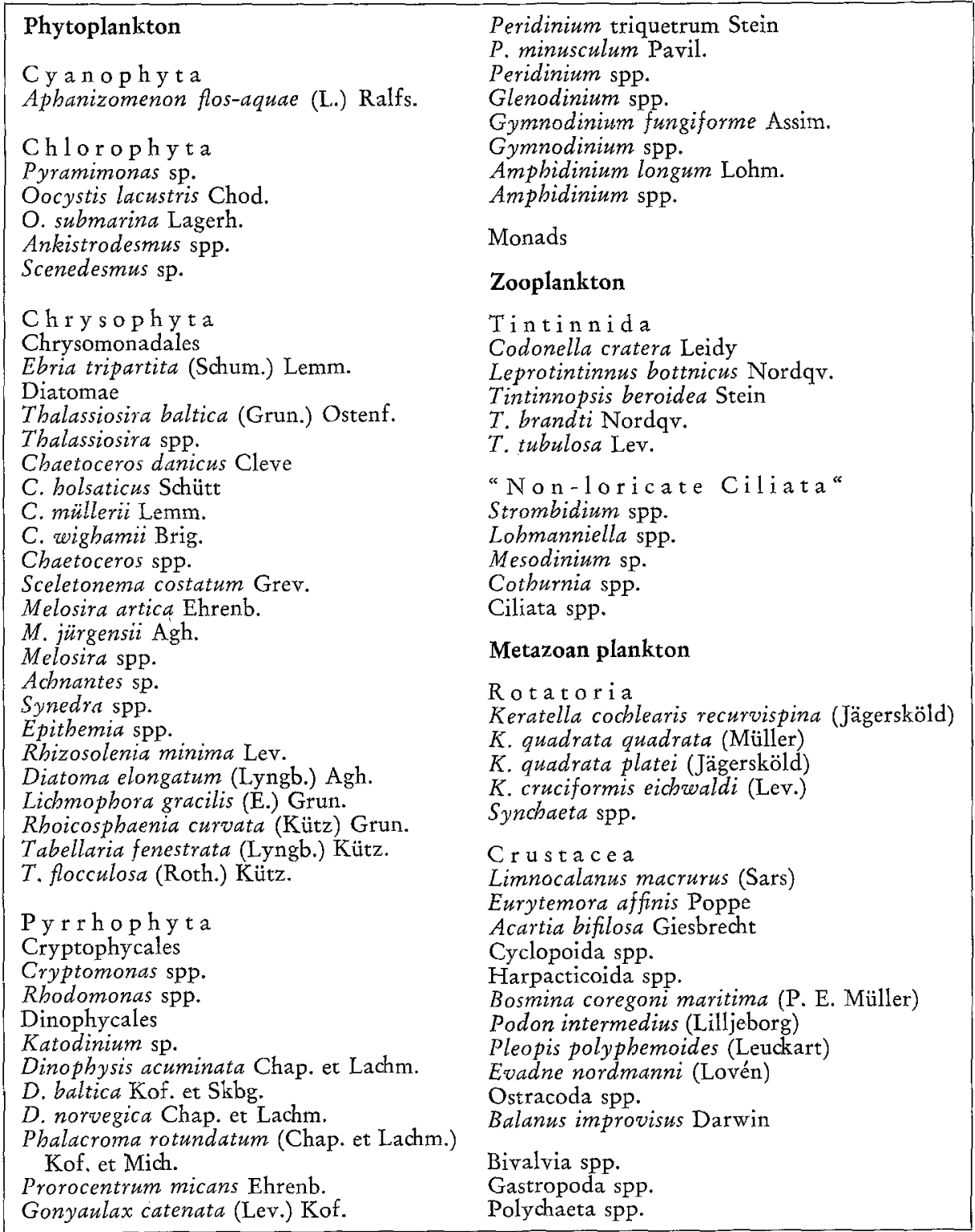

Ebria tripartita may reach peak densities from June to September. The species did not reach high abundance levels.

Thalassiosira spp., Chaetoceros spp., and Sceletonema costatum had their density peaks during the spring bloom in March and April. Chaetoceros spp. and Thalassiosira 
spp. were found during the whole investigation period although the former genus was considerably more numerous. $S$. costatum was scarce or non-existent after the spring bloom. Other diatoms appeared only in low densities.

Cryptomonas spp. and Rhodomonas spp. occurred in high densities during the whole investigation period. Abundance peaks were reached between July and November. The density was highest during 1973 .

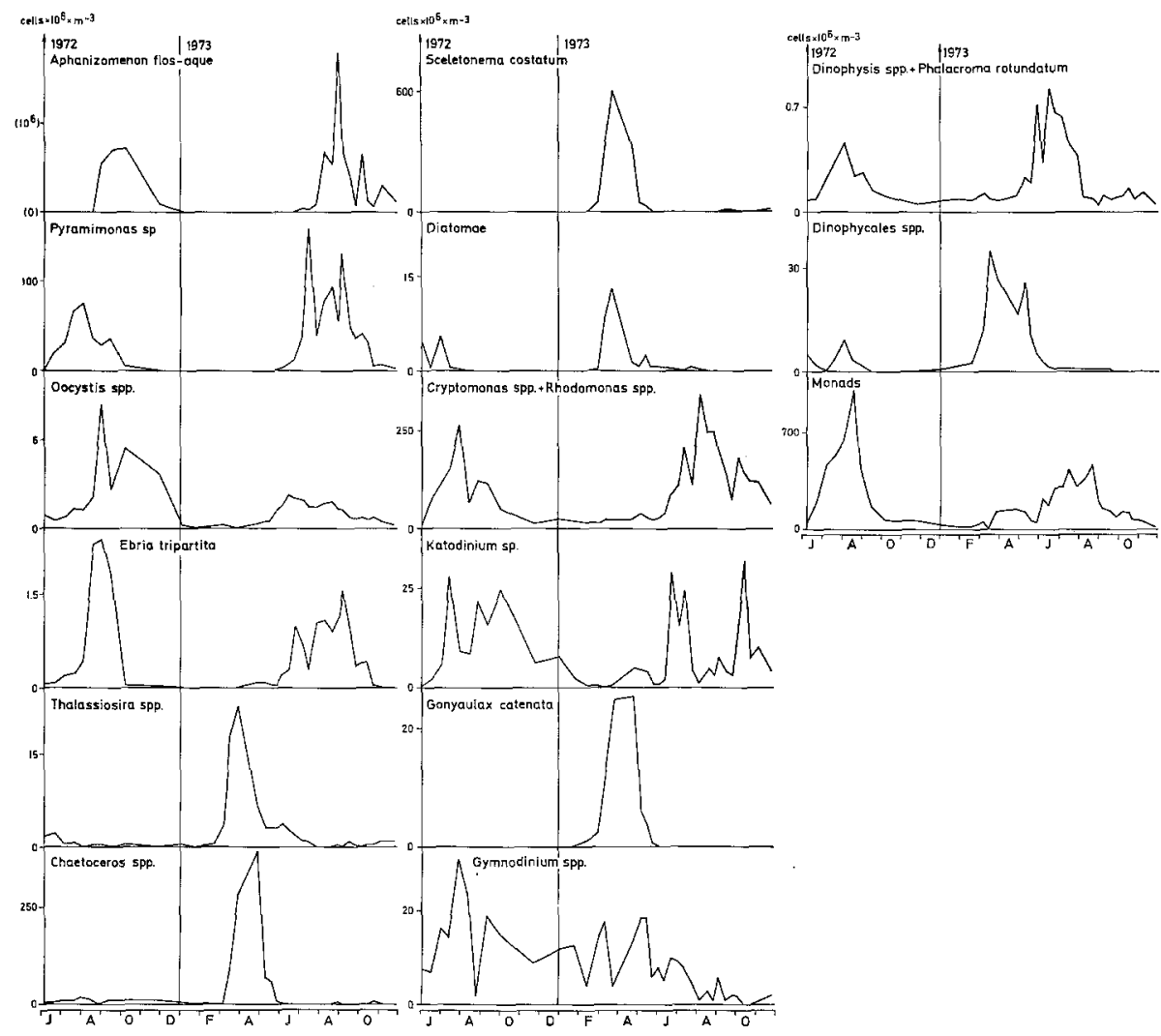

Fig. 3: Phytoplankton. Seasonal distributions of important taxa, June 1972-November 1973. Density, cells $\times 10^{6} \mathrm{~m}^{-3}\left(\mu \mathrm{m} \mathrm{m}^{-3}\right.$ for Aphanizomenon flos-aquae) in the upper $25 \mathrm{~m}$ water column

Katodinium sp. occurred mainly during the second half of the year. Gonyaulax catenata, on the other hand, was a typical spring bloom species. Small Gymnodinium spp. appeared in varying densities throughout the whole investigation period. All the taxa listed above appeared in low densities which are even more accentuated for Dinopbysis spp. and Phalacroma rotundatum. Peak abundances were recorded from May to August with a tendency for earlier occurrence in 1973. During this year the peaks were also higher. Other species of Dinophycales appeared mainly from March to May. 
Monads occurred in large numbers during the whole investigation period. Peak figures were recorded from June to August. The density was highest in 1972.

The protozoan plankton is here represented by various ciliate taxa (Fig. 4). Tintinnida spp. reached their highest densities in March and May with a secondary peak in August-September. Non-loricate ciliates always appeared in high densities.

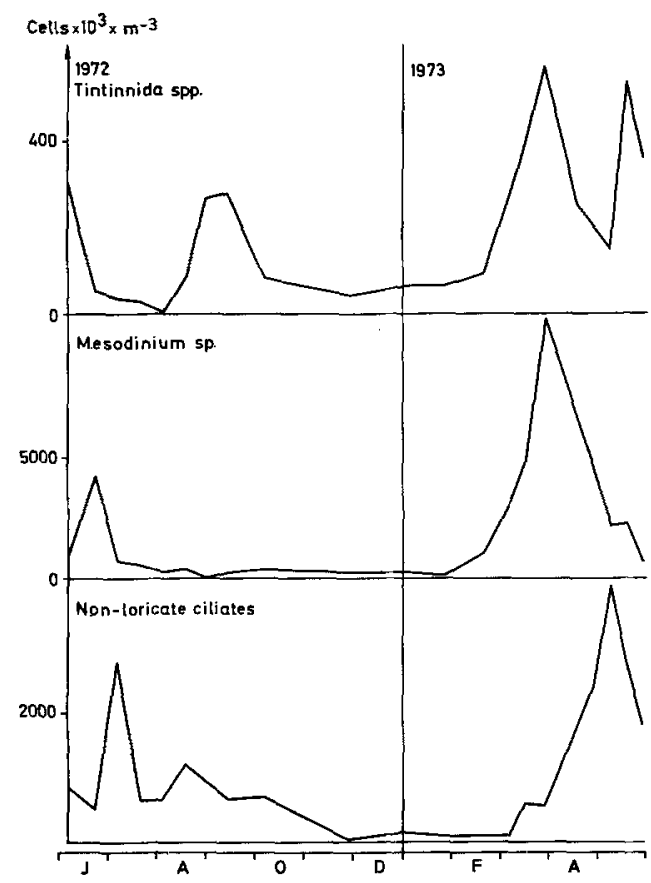

Fig. 4: Protozoan plankton. Seasonal distributions of important taxa, June 1972-May 1973. Density in the upper $25 \mathrm{~m}$ water column

The most abundant species was Mesodinium sp. which reached a considerable first peak in March-April and a second peak in June. Other non-loricate forms were most abundant in May and July.

Limnocalanus macrurus occurred in an irregular pattern and the ranges of variation were large (Fig. 5). However, abundance peaks were not usually recorded during the summer. Acartia bifilosa and Eurytemora affinis, which were the most abundant metazoan plankters, occurred in low densites during the first half of the year. From June the figures started to rise. E. affinis reached two considerable peaks in August and October while $A$. bifilosa produced a more even curve. After October the values diminished.

The cladocerans occurred mainly from July to September. Bosmina coregoni maritima, an abundant species, showed a tendency to occur somewhat later than Evadne nordmanni and Pleopis polyphemoides. The latter two species were far less abundant during 1973 than 1972. It is interesting that the large, open-sea form 


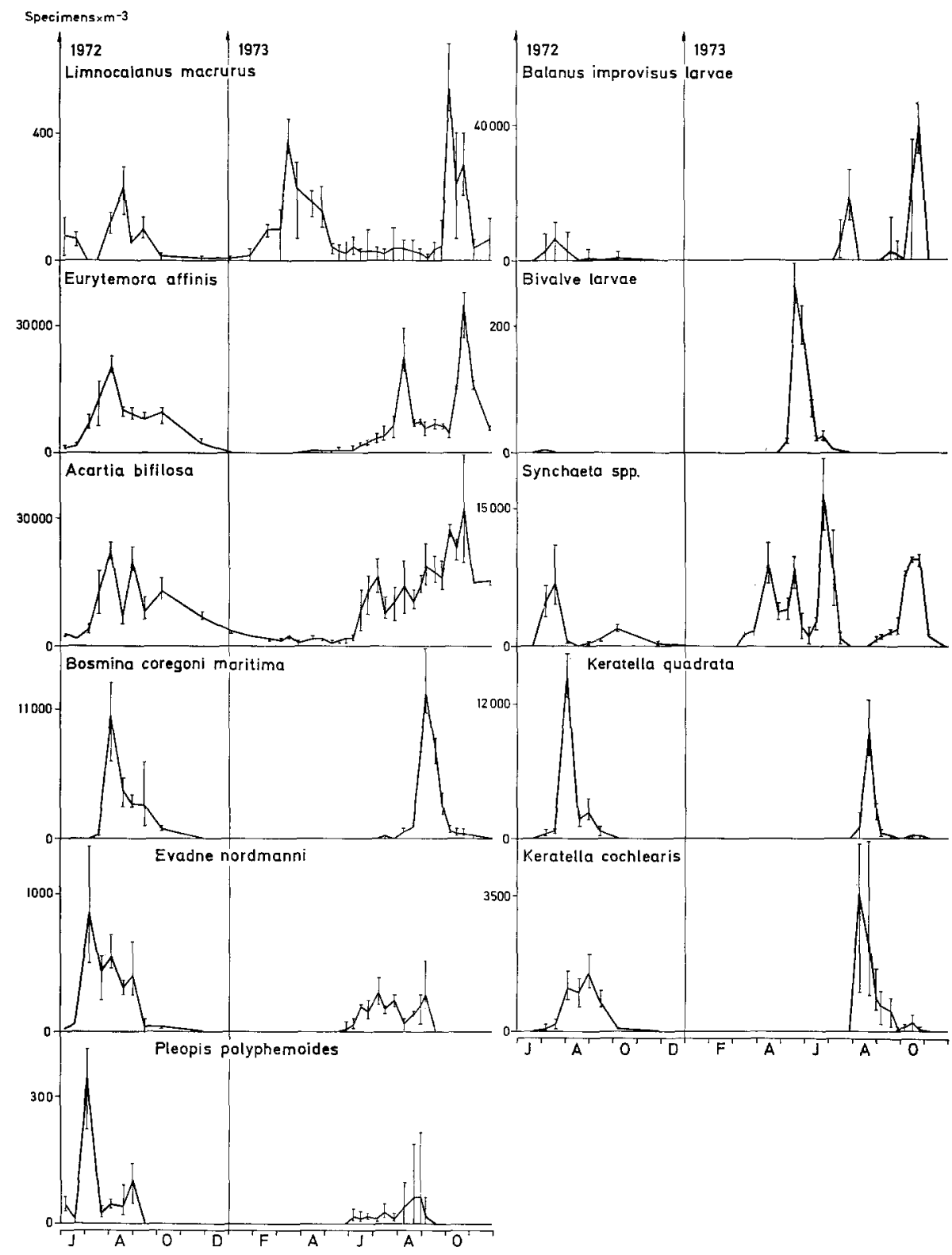

Fig. 5: Metazoan plankton. Seasonal distributions of important taxa, June 1972-November 1973. Density in the upper $40 \mathrm{~m}$ water column. Vertical bars denote ranges of variation 
Podon intermedius was more numerous than Pleopis polyphemoides on all sampling occasions during 1973.

Larvae, mainly nauplii, of Balanus improvisus reached density peaks in July and October 1973. The figures were much lower in 1972. Bivalve veligers had a considerable density peak in April.

Synchaeta spp. mainly occurred from March to October and reached considerable density peaks in April, May, June, and October. Keratella quadrata was very abundant in August. $K$. cochlearis was less numerous than the above-mentioned species. Its main occurrence was during August and September.
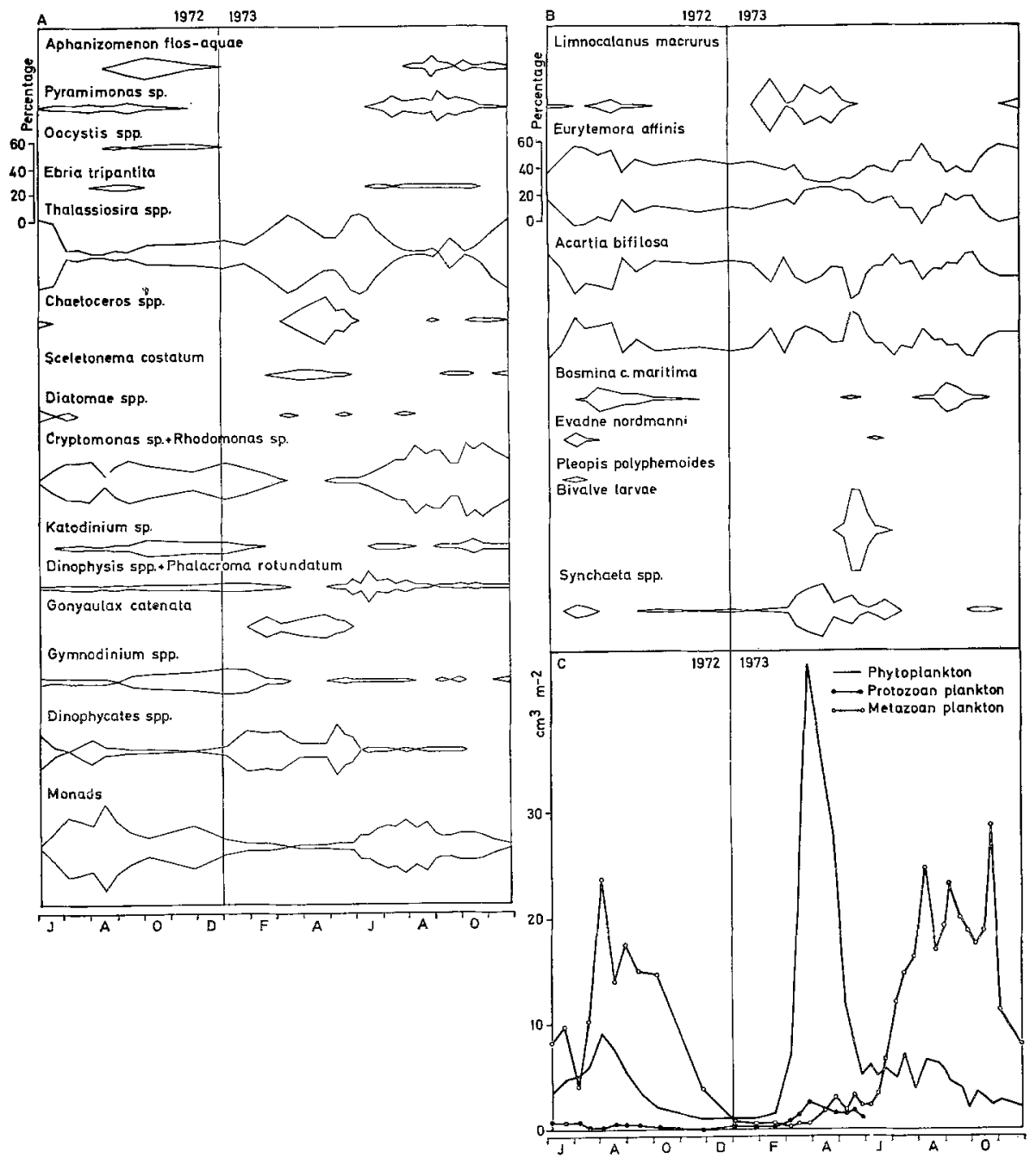

Fig. 6: Volume dominance. A: Percentage composition of phytoplankton; B: Percentage composition of metazoan plankton; C: Seasonal variations of volume 


\section{Volumedominance}

The plankton flora was dominanted by diatoms $(53 \%$ of the total phytoplankton standing crop) (Table 2). Thalassiosira spp. was the most important taxon. Within

Table 2

Dominance of phytoplankton, protozoan and metazoan plankton during June 1972-May 1973. Accumulated values $\mathrm{m}^{-2}$

\begin{tabular}{|c|c|c|c|}
\hline \multirow[b]{2}{*}{ Planktonic organisms } & \multicolumn{2}{|c|}{ Volume } & \multirow{2}{*}{$\begin{array}{c}\text { Number } \\
\times \quad 10^{6} \text { cells }\end{array}$} \\
\hline & $\times 10^{3} \mathrm{~cm}^{3}$ & $\%$ & \\
\hline \multicolumn{4}{|l|}{ Phytoplankton } \\
\hline (1) Thalassiosira spp. & 662 & 36 & 66 \\
\hline $\begin{array}{l}\text { (2) Dinophycales spp. } \\
\text { (excl. } 5,8,9,11)\end{array}$ & 252 & 14 & 144 \\
\hline (3) Chaetoceros spp. & 225 & 12 & 899 \\
\hline (4) Monads & 206 & 11 & 4125 \\
\hline (5) Gonyaulax catenata & 147 & 8 & 74 \\
\hline $\begin{array}{l}\text { (6) Cryptomonas spp. }+ \\
\text { Rhodomonas spp. }\end{array}$ & 122 & 7 & 1215 \\
\hline (7) Sceletonema costatum & 78 & 4 & 346 \\
\hline (8) Gymnodinium spp. & 39 & 2 & 262 \\
\hline $\begin{array}{l}\text { (9) Dinophysis spp. }+ \\
\text { Pbalacroma rotundatum }\end{array}$ & 29 & 2 & 4 \\
\hline (10) Pyramimonas sp. & 20 & 1 & 263 \\
\hline (11) Katodinium sp. & 15 & 1 & 153 \\
\hline $\begin{array}{l}\text { (12) Diatomae spp. } \\
\text { (excl. } 1,3,7)\end{array}$ & 15 & 1 & 25 \\
\hline (13) Aphanizomenon flos-aquae & 10 & 1 & 205 \\
\hline (14) Ebria tripartita & 8 & - & 8 \\
\hline (15) Oocystis spp. & 4 & 一 & 30 \\
\hline \multicolumn{4}{|l|}{ Protozoan plankton } \\
\hline (1) Mesodinium sp... & 56 & 35 & 37 \\
\hline $\begin{array}{l}\text { (2) Non-loricate Ciliata } \\
\text { (excl. 1) }\end{array}$ & 53 & 33 & 21 \\
\hline (3) Tintinnida spp. & 50 & 32 & 4 \\
\hline \multicolumn{4}{|r|}{ x $10^{3}$ specimens } \\
\hline (1) Acartia bifilosa & 638 & 47 & 115 \\
\hline (2) Eurytemora affinis & 488 & 36 & 81 \\
\hline (3) Bosmina c. maritima & 85 & 6 & 21 \\
\hline (4) Limnocalanus macrurus & 53 & 4 & 2 \\
\hline (5) Synchaeta spp. & 37 & 3 & 46 \\
\hline (6) Bivalve larvae & 36 & 3 & 91 \\
\hline (7) Evadne nordmanni & 11 & 1 & 3 \\
\hline (8) Pleopis polyphemoides & 2.4 & - & .6 \\
\hline (9) Keratella quadrata & 1.6 & - & 20 \\
\hline $\begin{array}{l}\text { (10) Cyclopoida spp. }+ \\
\text { Harpacticoida spp. }\end{array}$ & 1.2 & - & .3 \\
\hline (11) Podon intermedius & .80 & - & .1 \\
\hline (12) Polychaete larvae & .32 & - & .07 \\
\hline (13) Balanus improvisus & .24 & - & .06 \\
\hline (14) Ostracoda spp. & .20 & - & .01 \\
\hline (15) Keratella cocblearis & .16 & - & 5 \\
\hline (16) Gastrpod larvae & .012 & - & .03 \\
\hline (17) Keratella cruciformis & .004 & - & .1 \\
\hline
\end{tabular}


the protozoan plankton the most important species was Mesodinium sp. which constituted $35 \%$ of the total protozoan standing crop. The metazoan plankton was strongly dominated by the copepods which constituted $87 \%$ of the total metazoan standing crop.

The spring bloom occurred during March-April with a maximum value of $45.0 \mathrm{~cm}^{-3} \mathrm{~m}^{-2}$ (Fig. 6). During this period the diatoms Thalassiosira spp., Chaetoceros spp., and Sceletonema costatum and the dinoflagellate Gonyaulax catenata dominated. After the spring bloom the general trend of the phytoplankton volume was towards diminishing figures (range 1.0-12.0 $\mathrm{cm}^{-3} \mathrm{~m}^{-2}$ ). During May-June Thalassiosira spp. were still dominating but were later succeeded by small forms such as Cryptomonas spp., Rbodomonas spp., and monads. However, Thalassiosira spp. were always of relatively great importance because of their large size and numerical density. Blue-green algae were never of any major importance.

The protozoan plankton reached fairly large volumes during March-May (max. value $2.5 \mathrm{~cm}^{-3} \mathrm{~m}^{-2}$ ) but during the rest of the year the figures were low (range $\left..004-.033 \mathrm{~cm}^{-3} \mathrm{~m}^{-2}\right)$.

The metazoan plankton volume was relatively low from November to June (range of means .2-9.8 $\mathrm{cm}^{-3} \mathrm{~m}^{-2}$ ) but from July to October the figures were high (range of means $10.2-29.2 \mathrm{~cm}^{-3} \mathrm{~m}^{-2}$ ). During most of the year the copepods Acartia bifilosa and Eurytemora affinis dominated. Other taxa such as bivalve veligers and the rotifers Synchaeta spp. were occasionally of importance.

\section{DISCUSSION}

\section{Composition of the plankton community}

Bagge \& Lehmusluoto (1971) and Niemi (1972a) have discussed phytoplankton and primary production in relation to eutrophication in Finnish coastal waters. These papers offer an excellent opportunity for comparison with the present results. The Oregrundsgrepen may thus be classified as an oligotrophic area according to the following criteria: (a) the diversity is comparably large, (b) the phytoplankton biomass is large in spring but small in summer, (c) the spring bloom is dominated by diatoms and dinoflagellates, and (d) the trophogenic layer is considerably thicker than $10 \mathrm{~m}$ during the summer.

The metazoan plankton fauna is of low diversity. The two dominating species, viz. Acartia bifilosa and Eurytemora affinis, constitute $83 \%$ of the biovolume and only 7 important taxa (probably not more than 9 species) constitute more than $99 \%$. This indicates that the fauna is under environmental stress. The low salinity (5-6\% $\mathrm{S}$ ) should be the major limiting factor (cf. Remane, 1940). The protozoan plankton fauna is more difficult to cope with because of the low degree of taxonomical separation. However, all tintinnids were determined to species and only 5 were recorded. In comparison Hedin (1975) found 28 species in the more saline waters on the Swedish west coast $(25-35 \%$ on $)$. 
Estimation of biomass was done according to $1 \mathrm{~cm}^{3}=1 \mathrm{gwwt}_{\mathrm{w}}=0.05 \mathrm{~g} \mathrm{C}$ (cf. Mullin, 1969). The average phytoplankton biomass in the Oregrundsgrepen is $0.5 \mathrm{~g} \mathrm{C} \mathrm{m}^{-2}$ based on data from June 1972 to May 1973 and $0.4 \mathrm{~g} \mathrm{C} \mathrm{m}^{-2}$ based or.

Table 3

Estimation of biomass $\left(\mathrm{g} \mathrm{C} \mathrm{m}^{-2}\right)$ of phytoplankton, microzooplankton, and mesozooplankton in the Oregrundsgrepen during June 1972-November 1973. Average per sampling occasion

\begin{tabular}{|cccccc|}
\hline Sampling date & $\begin{array}{c}\text { Phyto- } \\
\text { plankton }\end{array}$ & Ciliates & $\begin{array}{c}\text { Microzooplankton }(<0.2 \mathrm{~mm}) \\
\text { Micro- } \\
\text { rotifers }\end{array}$ & Nauplii & $\begin{array}{c}\text { Meso- } \\
\text { zooplankton } \\
(>0.2 \mathrm{~mm})\end{array}$ \\
\hline $\begin{array}{l}1972-06-06 / \\
1973-05-28 \\
1973-01-02 / \\
1973-11-28\end{array}$ & 0.464 & 0.040 & 0.004 & 0.010 & 0.312 \\
\hline
\end{tabular}

data from January to November 1973 (Table 3). Preliminary reports from the western Åland Sea and nothern Bothnian Sea suggest lower figures, viz. 0.2 to $0.3 \mathrm{~g} \mathrm{C} \mathrm{m}^{-2}$ (calculated from wet weight by the authors; Ackefors \& Lindahl, 1975a, b). Unfortunately, data on primary production are not available for the Oregrundsgrepen. However, Niemi (1972b) reported an annual phytoplankton production of $48-66 \mathrm{~g} \mathrm{C} \mathrm{m}^{-2}$ for inshore and offshore waters at Tvärminne (northwest Gulf of Finland) during 1967-1971. Fonselius (1972) gave $57 \mathrm{~g} \mathrm{C} \mathrm{m}^{-2}$ year $^{-1}$ for central Bothnian Sea during 1961-1968 and Ackefors \& Lindahl (1975a, b) 70-94 $\mathrm{g} \mathrm{C} \mathrm{m}^{-2}$ year ${ }^{-1}$ for western Åland Sea and northern Bothnian Sea during 1973-1974. However, these data are not directly comparable owing to differences in methods and sampling intensities but the general tendency seems to be towards lower values than suggested by Ryther (1970) for neritic waters, i.e. $100 \mathrm{~g} \mathrm{C} \mathrm{m}^{-2}$ year-1. Although it is clear that there is poor correlation between standing crop and primary production (cf. Paasche, 1960; Bagge \& Niemi, 1971), indication is obtained that the Oregrundsgrepen is a somewhat more productive coastal area in a region of low primary production. Upwellings along the mainland may be responsible for this situation.

The average mesozooplankton biomass (specimens larger than $0.2 \mathrm{~mm}$ ) in the Oregrundsgrepen is $0.3 \mathrm{~g} \mathrm{C} \mathrm{m}^{-2}$ based on data from June 1972 to May 1973 and $0.5 \mathrm{~g} \mathrm{C} \mathrm{m}^{-2}$ based on data from January to November 1973 (Table 3). These figures are of the same magnitude as the values reported by Ackefors (1975) from open waters in the Baltic proper during 1968-1970, viz. $0.5 \mathrm{~g} \mathrm{C} \mathrm{m}^{-2}$ (calculated from wet weight by the authors). It has earlier been suggested by Eriksson (1973b) that the Oregrundsgrepen is richer in mesozooplankton specimens than the open waters of the Bothnian Sea (cf. Lindquist, 1959). The present data point in the same direction. 


\section{The relative importance of micro-and mesozooplankton}

In a series of papers, Beers \& Stewart (cf. 1971) reported on the occurrence of microzooplankton of the upper waters of eastern Pacific. These authors repeatedly emphasized the significance of microzooplankton in the marine food web. However, the nutritional demands of microzooplankton are by no means clearly defined. Zeitzschel (1967) e.g., suggested that tintinnids feed on detritus, bacteria, and algae, while Hedin (1975) showed that tintinnid cytoplasm usually contains considerable amount of algal remains, e.g. the dinoflagellates Prorocentrum and Katodinium. During many years of rearing experiments with this taxon, Gold (1973) fed them various algal species. An indication of the trophic relationship between phytoplankton and microzooplankton is the fact that large standing crops tend to co-occur in time. Similar observations were made on a spatial basis by Beers \& Stewart (1971) and Margalef (1973). However, it seems doubtful that all size groups of algae are suitable as food for microzooplankton. Certain microzooplankton species may also partly be autotrophic. These questions are presently left open.

For the investigation area, an attempt is made in Table 4 to elucidate the relative importance of micro- and mesozooplankton in the energy flow. This estimate implies that (a) $100 \%$ of the phytoplankton production is consumed by zooplankton, (b) microzooplankton only feeds on phytoplankton, and (c) the biomass figures are reliable. In this case about $60 \%$ of the primary production is consumed by microzooplankton. However, neither assumption (a) nor (b) are altogether correct. The accuracy of the microzooplankton figures is probably less than that of the mesozooplankton. Furthermore, the turn-over time of the ciliates is based on laboratory experiments and only on guesses concerning micro-rotifers. Bearing this in mind, it may nevertheless be suggested that this crude calculation indicates the correct magnitude of the energy flow through these size groups of the plankton fauna. It is interesting that Beers \& Stewart (1971) estimated the corresponding value to $70 \%$ in a transect across the California current during February-March 1968. In the present study, the microzooplankton constitutes $15 \%$ of the total zooplankton biomass calculated on an annual basis. The corresponding figure for the waters off La Jolla, California, was 17-21\% during April to September (Beers \& Stewart, 1970) which is of the same magnitude as the figures from investigations of shorter duration in the eastern Pacific by these authors (cf. e.g. Beers \& Stewart, 1971). Table 4 also shows that ciliates are the dominating group of the microzooplankton in the brackish water of the Oregrundsgrepen. A parallel may be drawn with coastal waters of full salinity in the western Mediterranean where Margalef (1967) suggested that ciliates contribute as much or even more to the organic production as does net zooplankton. In summary, it seems that microzooplankton, and especially ciliates, play a decisive role within the pelagic biocoenosis.

In a second step they are probably devoured by mesozooplankton as, e.g., Elbrächter (1970) found large amounts of tintinnid thecae in copepod feces in a semiclosed bay in the southern Baltic proper. 
Plankton community

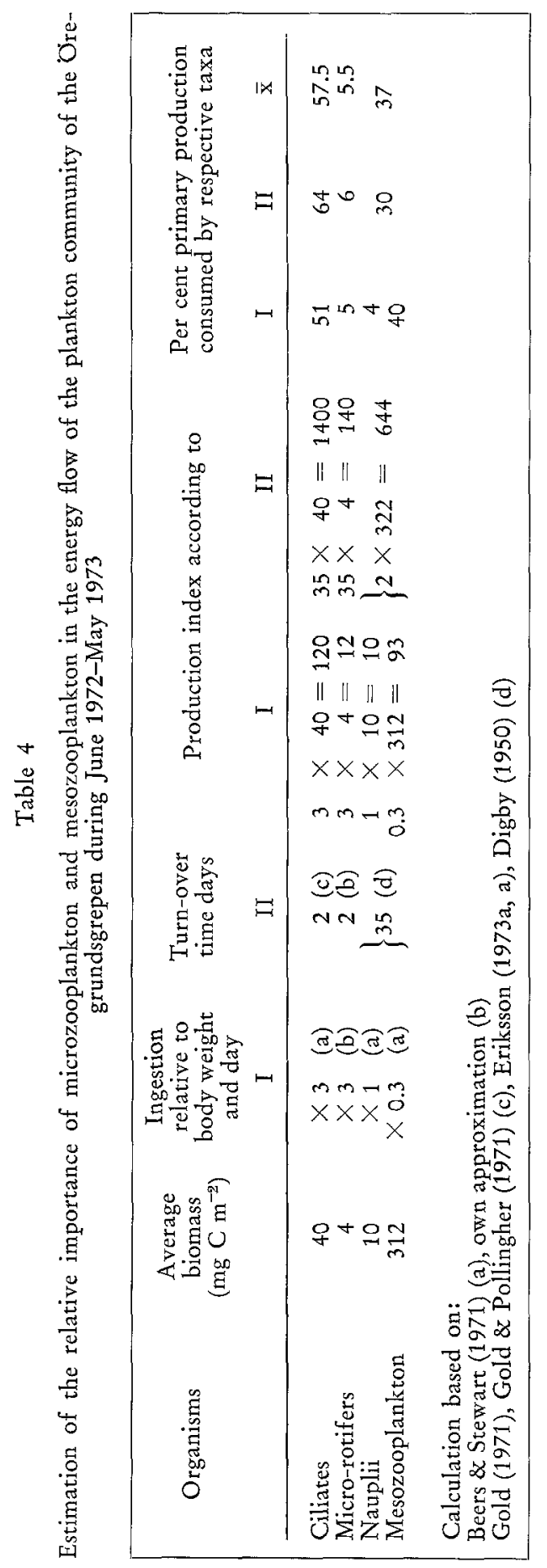


Acknowledgements. This investigation was financed by the Swedish Natural Environment Protection Board and working facilities were supplied by the Institute of Zoology at Uppsala University. The authors express their warmest gratitude to Professor K.-G. Nyholm, Institute of Zoology, Uppsala, and to the project leader Associate Professor U. Grimås, the Swedish Natural Environment Protection Board, for valuable support and advice. The discussion on phytoplankton with Assistant Professor K. Thomasson, Institute of Ecological Botany, Uppsala, and on microzooplankton with Dr. H. Hedin, Institute of Zoology, Uppsala, are gratefully acknowledged. The data on salinity, winds, and currents were kindly submitted by the Swedish Meteorological and Hydrological Institute.

\section{LITERATURE CITED}

Ackefors, H., 1975. Production studies of zooplankton in relation to the primary production in the Baltic proper. Merentutkimuslait. Julk. 239, 123-130.

- \& Lindahl, O., 1975a. Investigation on primary phytoplankton production in the Baltic in 1973. Meddn Havsfiskelab. Lysekil 179, 1-14.

$-1975 \mathrm{~b}$. Investigations on primary phytoplankton production in the Baltic in 1974. Meddn Havsfiskelab. Lysekil 195, 1-13.

Anonymous, 1912. Bull. plankt. 1908-1911, 1-62.

Bagge, P. \& Lehmusluoto, P. O., 1971. Phytoplankton primary production in some Finnish coastal areas in relation to pollution. Merentutkimuslait. Julk. 235, 3-18.

- \& Niemi, Å., 1971. Dynamics of phytoplankton primary production and biomass in Loviisa archipelago (Gulf of Finland). Merentutsimuslait. Julk. 233, 19-41.

Beers, J. R. \& Stewart, G. L., 1970. Numerical abundance and estimated biomass of microzooplankton. Bull. Scripps Instn Oceanogr. Tech. Ser. 17, 67-87.

- 1971. Micro-zooplankters in the plankton communities of the upper waters of the eastern tropical Pacific. Deep Sea Res. 18, 861-883.

Digby, P. S. B., 1950. 'The biology of small planktonic copepods of Plymouth. J. mar. biol. Ass. U. K. 29, 393-438.

Elbrächter, M., 1970. Phytoplankton und Ciliaten. Kieler Meeresforsch. 26, 193-203.

Eriksson, S., 1973a. The biology of marine planktonic Copepoda on the west coast of Sweden. Zoon 1, 37-68.

- 1973b. Preliminary zooplankton investigations in the Oregrund archipelago (southwestern Bothanian Sea) during the summer 1970. Zoon 1, 95-111.

- On the ecology of the copepods Eurytemora affinis Poppe and Acartia bifilosa Giesbrecht in the Oregrundsgrepen (southwest Bothnian Sea). (In prep.).

Fonselius, S. H., 1972. On primary production in the Baltic. Meddn Havsfiskelab. Lysekil 134, $1-3$.

Gold, K., 1971. Growth characteristics of the mass-reared tintinnid Tintinnopsis beroidea. Mar. Biol. 8, 105-108.

- 1973. Methods for growing tintinnids in continuous culture. Am. Zool. 13, 203-208.

- \& Pollingher, U., 1971. Microgamete formation and the growth rate of Tintinnopsis beroidea. Mar. Biol. 11, 324-329.

Hedin, H., 1975. On the ecology of tintinnids on the Swedish west coast. Zoon 3, 125-140.

Hernroth, L. Studies on the population dynamics of Eurytemora sp. in the Bothnian Sea. (Paper read at the meeting of the Baltic Marine Biologists at Gdynia, Poland, 1975.)

Hessle, C. \& Vallin, S., 1934. Investigations of plankton and its fluctuations in the Baltic during the years 1925-1927. Svenska hydrogr.-biol. Kommn Skr. (Biol.) 1 (5), 1-132.

Lindquist, A., 1959. Studien über das Zooplankton der Bottensee. II: Zur Verbreitung und Zusammensetzung des Zooplanktons. Rep. Inst. mar. Res. Lysekil (Biol.) 11, 1-136.

- 1961. Untersuchungen an Limnocalanus (Copepoda, Calanoida). Rep. Inst. mar. Res. Lysekil (Biol.) 13, 1-124. 
Margalef, R., 1967. El ecosistema. In: Ecologia marina. Fundatión la salle de ciencias naturales, Caracas 14, 377-453.

- 1973. Distribución de los ciliados planctónicos en la región de afloramiento del noroeste de Africa. Resultados exp. cient. B/O Cornide (Suppl. to Investigación pesq.) 2, 109-124

Mullin, M. M., 1969. Production of zooplankton in the ocean: The present status and problems. Oceanogr. mar. Biol. 7, 293-314.

Niemi, $\AA .$, , 1972a. Observations on phytoplankton in eutrophied and noneutrophied waters of the southern coast of Finland. Memo. Soc. Fauna Flor. fenn. 48, 63-74.

- 1972b. Annual phytoplankton primary producation in the archipelago and sea zones at Trärminne, Gulf of Finland. IBP Norden 10, 17-21.

Paasche, E., 1960. On the relationship between primary production and standing stock of phytoplankton. J. Cons. int. Explor. Mer 26, 33-47.

Pejler, B., 1972. Rotifer plankton in brackish and freshwater localities in central Sweden. Oikos 23, 416-419.

Remane, A., 1940. Einführung in die Zoologische Ökologie der Nord- und Ostsee. Tierwelt Nord- und Ostsee, 1a, 1-238.

Ryther, J. H., 1970. Photosynthesis and fish production in the sea. Science, N. Y. 166, 72-76.

Schnese, W., 1969. Untersuchungen über die Produktivität der Ostsee. II. Das Phytoplankton in der mittleren Ostsee und in der Bottensee im April/Mai 1967. Beitr. Meeresk. 26, 11-20.

Utermöhl, H., 1958. Zur Vervollkommung der quantitativen Phytoplankton-Methodik. Mitt. int. Verein. theor. angew. Limnol, $11(9), 1-38$.

Zeitschel, B., 1967. Die Bedeutung der Tintinniden als Glied der Nahrungskette. Helgoländer wiss. Meeresunters. 15, 589-601.

First author's address: Dr. S. Eriksson

Zoologiska institutionen

Box 561

S - 75122 Uppsala

Sweden 